\title{
Uzaktan Eğitim ile Coğrafya Öğretiminin Etkililiği Ölçeği: Ölçek Geliştirme, Geçerlik ve Güvenirlik Çalışması
}

DOI: $10.26466 /$ opus.879897

*

\section{Ziya İnce* - M.Mücahit Yentür** - Vedat Şahin ***}

* Dr., Namık Kemal Üniversitesi, Fen edebiyat Fakültesi, Coğrafya Bölümü Tekirdağ/Türkiye E-Posta: zince@nku.edu.tr ORCID: 0000-0001-7389-8083

** Dr., Milli Eğitim Bakanlığı, Şişli Milli Eğitim Müdürlüğü İstanbul/Türkiye E-Posta: myentur@hotmail.com

ORCID: 0000-0003-4382-7502

***Doç. Dr., Namık Kemal Üniversitesi, Fen edebiyat Fakültesi, Coğrafya Bölümü Tekirdağ/Türkiye

E-Posta: vsahin@nku.edu.tr

ORCID: 0000-0002-5502-5219

\section{Öz}

Bu araştırmanin amacl, coğrafya öğretmenlerinin uzaktan eğitimle gerçekleştirdiği coğrafya öğretiminin ne denli etkili olduğunu göstermek için kullanılacak geçerli ve güvenli bir ölçek geliştirmektir. Araştırmada oluşturulan ölçekte yer alan maddeler, araştırmacılar tarafindan literatür taranarak, madde havuzu oluşturularak ve uzman görüşü alınarak tespit edilmiştir. Araştırmanın evrenini İstanbul'daki coğrafya öğretmenleri oluştururken, örneklemini 2020-2021 öğretim yıl güz döneminde İstanbul'da görev yapan tesadüfi yöntemle seçilen 356 coğrafya öğretmeni oluşturmaktadır. Coğrafya öğretmenlerine uygulanarak elde edilen ölçek verileri, açımlayıcı ve doğrulayıcı faktör analizlerine tabi tutulmuş, analiz sonuçlarına göre 5'li likert tipinde, tek boyutlu ve 13 maddeden oluşan bir ölçek elde edilmiştir. Ölçeğin madde yükleri 45 ile .78 arasinda değer almakta ve uyum indeksi değerleri ise $\chi 2 / s d$ $=3.76, p<.01$, RMSEA $=.08, G F I=.90, C F I=.91, S R M R=.06, A G F I=.85^{\prime}$ dir. Ölçeğe ilişkin toplam varyansı \%43 ve ölçeğin tamamına ait Cronbach alpha iç tutarlık katsayısı 0,88 olarak tespit edilmiştir. Ölçek maddeleri ölçeğin tamamıyla yüksek düzeyde bir ilişki göstermektedir. Bu sonuçlara göre uzaktan eğitim ile coğrafya öğretiminin etkililĭği ölçeği geçerli ve güvenilirdir. Bu nedenle coğrafya öğretmenlerinin uzaktan eğitime yönelik tutumlarının ölçülmesinde kullanılabilir.

Anahtar Kelimeler: Coğrafya öğretmenleri, Coğrafya öğretimi, Uzaktan eğitim, Ölçek geliştirme, Geçerlik ve Güvenilirlik. 


\title{
Effectiveness Scale of Geography Teaching with Distance Education: Scale Development, Validity and Reliability Study
}

\begin{abstract}
The aim of this study is to develop a valid and safe scale to be used to show how effective geography teaching by distance education. The items in the scale created in the study were determined by the researchers by scanning the literature, creating an item pool and obtaining expert opinion. While the universe of the study is constituted of geography teachers in Istanbul, the sample is composed of 356 geography teachers who were chosen randomly in Istanbul in the 2020-2021 academic year. The scale data obtained by applying to geography teachers were subjected to explanatory and confirmatory factor analyzes, and a 5-point Likert-type, one-dimensional scale consisting of 13 items was obtained according to the analysis results. The item loads of the scale take values between .45 and .78 and the fit index values are $\chi 2 / s d=3.76, p<.01$, RMSEA $=.08, G F I=.90, C F I=.91, S R M R=.06, A G F I=.85$. The total variance for the scale was $43 \%$ and the Cronbach alpha internal consistency coefficient for the whole scale was 0.88. Hence scale items denoted a high level of correlation with the whole scale. According to these results, the scale of effectiveness of distance education in geography teaching is valid and reliable. According to these results, it can be used to measure the attitudes of geography teachers towards distance education.
\end{abstract}

Keywords: Geography teachers, Geography teaching, Distance education, Scale development, Validity, Reliability. 


\section{Giriş}

Günümüzde ulaşım, teknoloji ve bilgi hızla geliştiği için, Dünya üzerinde bilginin, ürünlerin ve hizmetlerin hızlı dağılımını sağlamaktadır. Gelişen bilgi ve iletişim teknolojileri; eğitim kurumların ve eğitim sistemlerini olumlu yönde etkilemiş, eğitim programları esnek yapısıyla mevcut ihtiyaca yanıt verebilmek adına şekillenmiş ve bilginin kontrollü bir biçimde eğitim kurumlarınca bireylere sunulmasını sağlamıştır (Usta, Uysal, ve Okur, 2016). Hem Türkiye' de hem de dünyada bu alanda hızlı bir değişim ve dönüşüm söz konusudur.

Disiplinler arası bir çalışma alanı olan açık ve uzaktan öğrenmeyi tanımlamak için farklı kavramlar kullanılmıştır. Bunlar: açı̈öğretim, uzaktan eğitim, uzaktan öğretim, e-öğrenme, internet tabanlı öğretim, internette eğitim, web destekli öğretim, yaygın eğitim, esnek öğrenme ve sanal eğitim bu farklı kavramlardandır. Bu kavramlar arasında küçük farklar olmakla birlikte evrensel literatürde genellikle birbirleri yerine kullanılmaktadır (Özkul ve Aydın, 2012). Açık ve uzaktan öğrenme kavramları Covid-19 salgını ile beraber çok büyük bir önem kazanmıştır. Öncelikle 2019 yılının sonlarında Çin'de başlayan Covid-19 salgını, 3 ay gibi kısa bir sürede bütün kıtalara yayılmış, Şubat 2021 itibariyle dünya üzerinde 2.222.647 insanın ölümüne sebep olmuştur (WHO, 2020). Dünya sağlık örgütü durumun daha da kötüleşeceğinden endişe etmektedir. Dünya nüfusunun büyük bir kısmını eve hapseden (Yılmaz M., 2020) Covid-19 salgını, bir sağlık krizi olmasına karşın, her ülkedeki eğitimi de hızlı bir şekilde etkilemiştir (UNESCO, 2020).

Covid-19 salgınına kadar uzaktan eğitim yöntemleri birçok ülke tarafından bazı öğretim kademelerinde kullanılsa da dünya genelinde yüz yüze örgün eğitim hiçbir zaman bu dönemdeki kadar terkedilmemiştir (Yllmaz, Güner, Mutlu, Doğanay ve Yılmaz, 2020). Türkiye'de Covid-19 vakalarının görülmesinden endişe edildiği için tedbir amaçlı 16 Mart 2020'den itibaren Bakanlık tarafından okullara ara verilmesine (MEB, 2020) ve 30 Mart 2020 tarihinden itibaren ise uzaktan eğitime geçilmesine karar verilmiştir.

Covid-19 salgınından önce uzaktan eğitim Türkiye'de sadece açıköğretim kurumlarının öğrencileri için sürdürülürken, salgın ile beraber bütün öğrenciler için gündeme alınmıştır. Gelişli (2015)'nin, farklı fiziksel mekânlardaki öğretmen ve öğrencilerin çeşitli iletişim teknolojileri yardımıyla öğretme-öğrenme faaliyetlerini gerçekleştirdiği bir sistem olarak tanımladığı uzaktan 
eğitimle ilk defa karşılaşan öğretmen ve öğrenciler, çeşitli zorluklar (Kurnaz ve Serçemeli, 2020) yaşamaktadır. OECD desteği ile Reimers ve Schleicher (2020)' in yaptığı araştırmaya göre, öğretmenlere hem mesleki hem psikolojik destek sağlanması gerekmektedir.

\section{Literatür Taraması}

Literatür tarandığında, uzaktan eğitim, çevrimiçi eğitim, e-öğrenme adında birçok çalışmanın yapıldığı görülmektedir. Thach ve Murphy (1995), uzaktan eğitim modelini çalışırken, Heuer ve King (2004), ABD'de çevrimiçi eğitimde eğitmenin rolü ve sorumluluklarını araştırmıştır. Lee ve Busch (2005), uzaktan eğitim yöntemlerini, geleneksel eğitimden ayıran öğeleri; Toker-Gökçe (2008)'nin Küreselleşme sürecinde uzaktan eğitim konularını; Düzakın ve Yalçınkaya (2020), web tabanlı uzaktan eğitim sistemi ile öğretim elemanlarının bu sisteme yatkınlıklarını; Özgöl, Sarıkaya ve Özürk (2017), örgün eğitim içerisinde uzaktan eğitim uygulamalarını; Pınar ve Dönel Akgül (2020) fen bilimleri dersinin uzaktan eğitim ile verilmesi konularında çalışmışlar yapmışlardır.

Uzaktan eğitim ile ilgili geliştirilen ölçek çalışmaları ise oldukça fazladır. Ağır, Gür ve Okçu (2007), öğretmenlerin uzaktan eğitime karşı tutumlarını belirlemek için 43 maddeden 6 faktörden oluşan ölçek hazırlamıştır. Haznedar ve Baran (2012), eğitim fakültesi öğrencilerinin e-öğrenmeye yönelik tutumlarını ölçmek için 20 madde ve tek veya iki faktörden oluşan bir ölçek geliştirirken, Yıldırı S., Yıldırım G., Çelik ve Karaman (2014), uzaktan eğitim yöntemi ile eğitim alan bireylerin görüşlerini ortaya çlkaran 18 madde ve 4 faktör içeren bir ölçek oluştururken, Chou (2014), öğrencilerinin e-öğrenmeye yönelik tutumlarının belirlenmesine yönelik 26 madde ve 5 faktörden oluşan detaylı bir ölçek geliştirmiştir. Mishra ve Panda (2007), öğretim elemanlarının e-öğrenmeye yönelik tutumlarını belirlemek için 22 madde ve 2 faktörlü ölçeği, Usta vd. (2016)'nin üniversite öğrencilerinin çevrimiçi öğrenmeye ilişkin tutumlarını ölçmek için 20 madde ve 4 faktörden oluşan ölçeği ve Yıldız (2015)'ın öğretim elemanlarının uzaktan eğitime yönelik bilgi, inanç ve uygulamaları arasındaki ilişkilerini ölçmek için geliştirdiği ölçeği önemlidir.

Coğrafya öğretimi, uzaktan eğitim yöntemi ile gerçekleştirilirken kullanılan araçlar, teknikler, yöntemler ve tutumlar hakkında yapılan bazı nitel 
araştırmaların olduğu görülür (Yazıcı, 2015; Teyfur, 2016; Türker ve Dündar, 2020).

Coğrafya eğitimi konusunda hazırlanan ölçek çalışmaları incelendiğinde ise bu çalışmaların özellikle lise öğrencilerinin coğrafya dersine olan tutumlarını tespit etmeye yönelik olduğu anlaşılmaktadır (Alım, 2003; Özgen, 2009); Özgen, Bindak ve Birel, 2009; Uzunöz, 2011). Ayrıca Demir ve Koç (2013)'un Coğrafya dersi tutum ölçeği 15 madde ve 2 faktörden oluşmaktadır. Gümüş ve Özüpekçe (2013) 55 madde ve 2 faktörden oluşan bilgisayar destekli coğrafya öğretimine yönelik bir tutum ölçeği geliştirilmiştir. Çakıc1oğlu-Oban ve Aygören (2017)'in hazırladığ1; sosyal bilgiler öğrencilerinin coğrafya dersine yönelik tutumları konusundaki çalışma 50 soru ve tek boyuttan oluşmaktadır. İncelenen ölçekler arasında, Sözen (2019)'in hazırladığı, 25 madde ve 3 faktörden oluşan, coğrafya dersi tutumu, coğrafya ders işlenişi ve materyal kullanımına yönelik ölçeği; Kılcan, Çetin, Ablak, ve Gürgür (2019) tarafından geliştirilen; 23 madde ve 2 boyuttan oluşan, beşeri coğrafya dersine yönelik tutum ölçeği ile Deniz, İnel ve Sezer (2020)'in hazırladığı, 21 madde ve 4 faktörden oluşan, üniversite öğrencilerinin küresel iklim değişikliğine yönelik farkındalık ölçeği son dönemdeki en dikkat çekici ölçeklerdir. Ancak coğrafya öğretmenlerinin uzaktan eğitim ile ilgili tutumlarını ölçen bir ölçme aracı ile karşılaşılmamıştır.

\section{Amaç ve Önem}

Dünyada özellikle 2020 yılı başından itibaren yayılan Covid-19 salgını sebebiyle eğitimciler bütün eğitim kademelerinde bilgilerini sanal ortamda öğrencilerine aktarmaya başlamışlardır. Bu sebeple, araştırmanın amacı, uzaktan eğitim ile gerçekleştirilen coğrafya öğretiminin etkililiğini coğrafya öğretmenlerinin görüşlerine göre doğru bir şekilde ölçen, hızlı ve kolay değerlendirebilen, geçerli ve güvenilir bir ölçek geliştirmektir.

$\mathrm{Bu}$ alan yazından da anlaşıldığ 1 üzere uzaktan eğitim ve coğrafya eğitimi konularında birçok çalışma yapılmış olmasına karşın, uzaktan eğitim ile coğrafya öğretiminin etkililiği konusunda yapılmış çok fazla çalışma olmadığından, bu araştırmanın önemi artmaktadır. Ayrıca bu araştırmanın spesifik olarak coğrafya alanındaki eğitimi konu alması ve büyük bir örneklemle gerçekleştirilmesi değerini artırmaktadır. Bu yönüyle çalışmanın hem literatüre hem de kendi alanına katkı sağlayacağı düşünülmektedir. 


\section{Varsayımlar ve Sinırlılıklar}

Bu araştırmada kullanılan ölçme aracının, coğrafya öğretmenlerinin uzaktan eğitim ile coğrafya öğretiminin etkililiği konusundaki görüşlerini ölçtüğü ve var olan durumu yansıttığı varsayılmıştır.

Bu araştırma, 2019-2020 eğitim öğretim yılı güz döneminde; İstanbul ilindeki ortaöğretim okullarında görev yapan coğrafya öğretmenleri ile sınırlı tutulmuştur.

\section{Yöntem}

\section{Araştırma Modeli}

Coğrafya öğretmenlerinin uzaktan eğitim yöntem ile gerçekleştirdikleri coğrafya eğitiminin etkililiği hakkındaki görüşlerinin incelendiği bu araştırma, nicel araştırma yöntemi ve betimsel tarama deseni ile gerçekleştirilmiştir. Tarama deseni, geçmişte veya günümüzde var olan bir durumu olduğu biçimde tanımlamaya çalışan bir yaklaşımdır (Köse, 2017; Karasar, 2013). Bu desende daha çok araştırılan olayın mevcut durumunun ne olduğu araştırılır (Çepni, 2018). Ayrıca Karasar (2013) araştırma modelini, araştırma amacına uygun ve ekonomik olarak verilerin toplanması ve çözümlenebilmesi için gerekli koşulların düzenlenmesi olarak tanımlamaktadır. Genel tarama modelleri, örnekleme yoluyla evren hakkında kestirimlerde bulunur ve olabildiğince geniş bir örneklemden veri toplanır (Şimşek, 2018).

\section{Çalışma Grubu}

Araştırma evrenini İstanbul ilindeki coğrafya öğretmenleri oluştururken, araştırma örneklemini İstanbul'un 30 ilçesindeki coğrafya öğretmenleri oluşturmaktadır. Bilimsel araştırmalardaki örneklem kavramı Doğanay (2002), Karasar, (2013) ve Yeşil, (2014) tarafından gözlemlerin nispeten daha küçük bir grup üzerinde gerçekleştirilmesi ile evrenin bütün özelliklerinin yansıtılması şeklinde tanımlamaktadır. Bununla beraber Yıldırım ve Şimşek (2013, s. 129), evren yerine evreni temsil eden küçük bir grubun araştırma için incelenmesinin pratik bir çözüm olduğunu ifade etmiştir. 
Örneklem büyüklüğü tespit edilirken \%95 güven aralığında (Yazıcıŏlu ve Erdoğan, 2014) 333 katılımcıya anket uygulanması gerektiği belirlenmiştir. Bu doğrultuda İstanbul ilinde 2019 yılındaki 1608 coğrafya öğretmeni (Yentür, 2019) içinde 356'sına (\%22,14) gönüllü olarak ölçek uygulanarak maksimum çeşitlilik sağlanmış ve evren temsili sağlamıştır. Araştırmanın sonuçlarının kapsamının geçerliliği için en yüksek örneklem çeşitliliği sağladığı, çok sayıda farklı okul türünün bulunduğu, farklı çalışma kıdemlerinde görev yapanların çokluğu ve farklı sosyo-ekonomik özelliklere sahip ilçelerin varlığ1 İstanbul'daki coğrafya öğretmenlerinin tercih edilmesine neden olmuştur. Araştırmaya katılan 356 coğrafya öğretmenlerinin demografik bilgileri Tablo 01 'de yer almaktadır.

Tablo 1. Araştırmaya Katılan Coğrafya Öğretmenlerinin Demografik Özellikleri Frekans ve Yüzdelik Dă̆ılımı

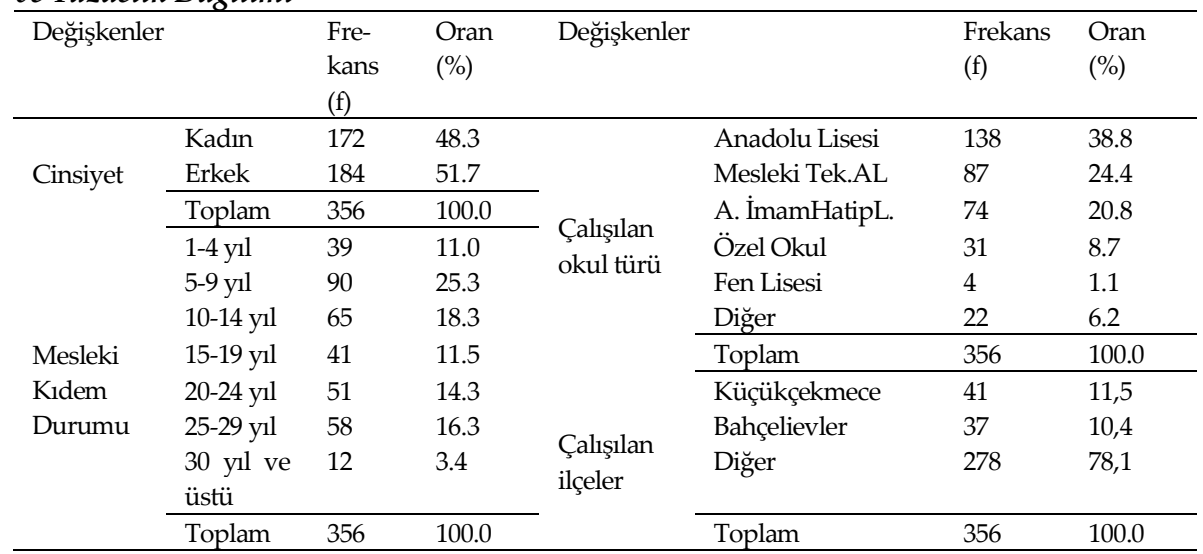

Tablo 01 incelendiğinde araştırmaya katılan coğrafya öğretmenlerinin \% 48,3'ü (172) kadın ve \% 51,7'si (184) ise erkelerden oluşmaktadır. Coğrafya öğretmenlerinin kıdem seviyelerinin eşit bir dağılım gösterdiği; \% 11'i (39) 14 yıl kıdeme, \% 25,3'ü (90) 5-9 yıl kıdeme, \% 18,3’ü (65) 10-14 yıl kıdeme, \% 11,5'i (41) 15-19 yıl kıdeme, \% 14,3'ü (51) 20-24 yıl kıdeme, \% 16,3'ü (58) 25-29 yıl kıdeme ve \% 3,4'ü (12) 30 yıl üstü kıdeme sahip olduğu anlaşılmaktadır. Katılımcıların okul türlerine göre dağılımı incelendiğinde 138 (\%38,8) kişi ile en büyük katılımın Anadolu Lisesi okul türünden olduğu görülmektedir. Araştırmaya katılan coğrafya öğretmenlerinin İstanbul'da çalıştıkları ilçelere göre dağılımına baktığımızda büyük bir çeşitliliğin olduğu görülmektedir. 
Tablo 01'de fazla yer kaplamaması için sadece en fazla katılım olan iki ilçenin değerleri verilmiştir. Diğer ilçelerin katılım sayıları şu şekildedir: Küçükçekmece 41, Bahçelievler 37, Şişli 24, Gaziosmanpaşa 23, Kadıköy 22, Esenyurt 20, Üsküdar 18, Sancaktepe 17, Sarıyer 17, Bakırköy 16, Ümraniye 14, Avcılar 12, Beşiktaş 12, Ataşehir, 11, Beylikdüzü 11, Esenler 11, Güngören 10, Kartal 10, Kağıthane 6, Beyoğlu 4, Zeytinburnu 4, Adalar 3, Bağcılar 3, Beykoz 2, Maltepe 2, Silivri 2, Başakşehir 1, Fatih 1, Pendik 1, Şile 1. İstanbul'un 9 ilçesinden ise katılım olmamıştır.

\section{Veri Toplama Aracı ve Ölçeğin Geliştirilme süreci}

İlk aşamada alan yazın incelenmiş ve uzaktan eğitim ile coğrafya öğretimi veren öğretmenlerin uzaktan eğitim hakkında görüşleri alınmıştır. Bu kapsamda yapılan çalışmalar ve öğretmen görüşleri incelenmiştir. Bunlardan bazıları; (Ağır vd. 2007; Çakıcığlu-Oban ve Aygören 2017; Chou 2014; Doğanay 2002; Demir ve Koç, 2013; Gümüş ve Özüpekçe 2013; Haznedar ve Baran 2012; İnce (2015), Kocalar ve Demirkaya (2017), Özey (2002), Sözen (2019); Şahin (2017) ve Ünlü (2014),). Araştırmalar sonucunda uzaktan eğitim ile coğrafya öğretiminin etkililiği konusunda 30 sorudan oluşan bir madde havuzu oluşturulmuştur. Soruların karşısına öğretmenlerin ifadelere katılma düzeylerini tespit etmek için beşli likert tarzında seçenekler eklenmiştir. Bu seçenekleri sırayla "(1)Hiç Katılmıyorum, (2)Katılmıyorum, (3)Kararsızım, (4) Katılıyorum ve (5)Tamamen Katilıyorum şeklinde puanlanmıştır.

Daha sonra oluşturulan 30 maddelik form, uzman görüşleri alınmak üzere konu alanında bilgi sahibi olan ve çalışma konusu hakkında bilgilendirilen eğitim bilimleri alanından ve coğrafya eğitimi alanından 6 uzmanın görüşüne sunulmuş ve maddeler uzmanlarla tartışlmıştır. Bu süreçte uzmanların vermiş olduğu görüşler doğrultusunda maddelerin kapsam geçerliği ve görünüş geçerliği belirlenmiştir. Kapsam geçerliğinin belirlenmesinde her bir madde için olumlu yanıt vermiş uzman sayısı toplamının, toplam uzman sayısına oranının bir eksiği alınmasu suretiyle tespit edilmiştir. Kapsam geçerlik oranı 0.80 'in altında olan maddeler ölçekten çıkarılarak 24 maddelik deneme formu elde edilmiştir. Hazırlanan ve henüz son hali verilmemiş olan ölçek pilot uygulama ile bir ilçede 27 coğrafya öğretmenine uygulanmış, görülen aksaklıklar ve aykırılıklar dikkate alınarak düzeltmeler yapılmıştır. Böylece pilot uygulama sonucunda ölçeğin geneli ile uyumsuz 6 madde 
çıkartılarak ölçeğe son hali verilmiştir. Problemi tanımlama, madde yazma, uzman görüşü alma ve ön uygulama yapma gibi anket geliştirme süreçleri (Büyüköztürk, 2005) takip edilerek 18 maddelik ölçek elde edilmiştir.

\section{Verilerin Toplanması ve Analizi}

Ölçek hazırlandıktan sonra; İstanbul il Milli Eğitim Müdürlüğünden alınan araştırma izni ve Namık Kemal Üniversitesi Bilimsel Araştırma ve Yayın Etiği Kurulu onayı ile uygulanmıştır.

Salgın sebebiyle okullar tatil olduğundan ölçek elektronik ortamda Googleform'a dönüştürülmüş ve bağlantısı öğretmenlere telefon grupları ve eposta yoluyla ulaştırılmıştır. Ölçek iki bölümden oluşmaktadır. Birinci bölümde demografik bilgiler, ikinci bölümde ise ölçek soruları yer almaktadır. 12 Kasım-1 Aralık 2020 tarihleri arasında İstanbul ilinde öğretmenlerin katılımına açık olan ölçek toplam 363 öğretmen tarafından doldurulmuştur. Formun başlangıcında öğretmenlerin gönüllülük onaylarını soran "Evet" ve "Hayır" soruları bulunmaktadır. Onay bölümündeki "Hayır" bölümünü işaretleyen 7 öğretmenin formu ayrılmış, geriye kalan gönüllü 356 öğretmenin formu işleme alınmıştır. Öğretmenlerden elde edilen veriler Googleform'dan Excel programına indirilmiş analizlerin yapılacağ 1 SPPS programına uyumlu hale getirilerek SPSS programında değerlendirilmiştir.

Araştırmada anketin yapı geçerliğini test etmek için faktör analizi yapılmıştır. Büyüköztürk (2012)'e göre faktör analizi, aynı yapıyı ya da niteliği ölçen değişkenleri bir araya toplayarak ölçmeyi az sayıda faktör ile açıklamayı amaçlayan bir istatistiksel yöntemdir. Araştırmalarda geçerlik ve güvenirlik inceleme yöntemleri ve kullanılan testlere göre farklılık göstermektedir (Karakoç ve Dönmez, 2014). Normallik testlerinde değerler +2 ile -2.0 arasında olduğunda sonucun normal olduğu kabul edilmektedir (George ve Mallery, 2005). Bu sebeple ölçekte hangi analizlerin gerçekleştirileceğine karar vermeden ölçeğin normallik testleri ve güvenirlik çalışmaları yapılarak analize uygun oldukları belirlenmiştir.

Ölçeğin veri analizinde, temel bileşenler analizi ve özellikle Varimax Dik Döndürme tekniği gerçekleştirilmiştir. Doğrulayıcı faktör analizinde ölçek yapısının uyumluluğunu test etmek için $\chi^{2}, \chi^{2} / \mathrm{sd}$, RMSEA, SRMR, CFI, GFI, IFI ve AGFI uyum indeksleri (Schermelleh-Engel, Moosbrugger, ve Müller, 2003) incelenmiştir. 


\section{Bulgular}

Coğrafya öğretmenlerinin uzaktan eğitim ile coğrafya öğretiminin etkililiğini ölçmek amacıyla; yapı geçerliği, ölçeğin toplam puanı, faktör korelasyon matrisi ve maddelerin toplam korelâsyonları hesaplanmıştır.

\section{Açımlayıcı Faktor Analizine (AFA) Yönelik Bulgular}

Araştırmaya katılmayı kabul eden toplam 356 öğretmenden elde edilen veriler doğrultusunda da ölçeğin geçerlik ve güvenirlik çalışmaları yapılmıştır. Araştırma kapsamında faktör analizinin yapılabilmesi için gerekli görülen örneklem büyüklüğü incelenmiş, çalışma grubu yeterli görülmüştür (Tabachnick ve Fidell, 2001). Ölçeğin yapı geçerliğini belirlemek için varimax döndürme ile temel bileşenler analizi kullanılarak açımlayıcı faktör analizi (AFA) yapılmıştır. Analizde faktör yükleri en az .40 olarak belirlenmiştir (Büyüköztürk, 2012). Ölçeğin alt boyutları ve toplam güvenirlikleri için Cronbach Alpha katsayısı hesaplanmıştır. Ayrıca AFA ile ortaya konulan yapının doğruluğunun test edilebilmesi için doğrulayıcı faktör analizi (DFA) yapılmiştır.

Bilimsel veriler çoğunlukla çok değişkenli yapıda olduğu için değişkenler arasındaki örüntüyü tespit etmek ve özetlemek oldukça önemlidir. Bu analiz için kullanılan yaklaşımlardan biri de, en genel tanımı ile çok değişkenli veri setlerinde değişkenler arasındaki örüntüyü ortaya çıaran faktör analitik yaklaşımıdır (Landau ve Everitt, 2004). Ölçeğin yapı geçerliliğini ortaya koymak ve maddelerin faktör yüklerini belirleyerek boyutlandırabilmek amacıyla faktör analizi yapılmıştır. Verilerin faktör analizine uygunluğunu saptamak üzere Kaiser-Meyer-Olkin (KMO) katsayısı ve Barlett Sphericity testi hesaplanmıştır. KMO değeri .895 bulunmuş ve Bartlett testi sonucu da $\left(\chi^{2}=2060.933, p=0.00\right)$ anlamlı çıkmıştır (George ve Mallery, 2005; Tavşancıl, 2019). Barlett testinin anlamlı çıkmış olması, verilerin çok değişkenli ve normal dağılım özelliğinde olduğunu göstermektedir. KMO değerinin 1'e yaklaşması ölçek hesaplamalarında ölçekteki her bir değişkenin, diğer değişkenler tarafından ne düzeyde tahminini ifade etmektedir. Barlett Küresellik testi ise verilerin çok değişkenli normal dağılımdan geldiğini ortaya çıarmak içindir (Büyüköztürk, 2012).

AFA sonucunda ölçeğin tek faktör altında toplandığı görülmüştür. Tek bir yapıyı ölçen ölçeklerde genellikle tek faktör ortaya çıkmaktadır (Uzgören, 
2012). Yeterli faktör yükü sağlamayan 5 madde ölçekten çıkartılarak (Büyüköztürk, 2012) analiz tekrarlanmıştır. Tek faktörlü yapının ölçeğe ilişkin açıkladığ1 varyans \%43.'tür. Tablo 2' de 13 maddenin özellikleri sunulmuştur.

Tablo 2. Ölçeği Oluşturan maddelerin Faktör yükleri

\begin{tabular}{llll}
\hline Ölçek Maddeleri & AFA & DFA & tDeğeri \\
\hline M1 & .74 & .71 & 7.68 \\
M2 & .78 & .76 & 7.86 \\
M3 & .59 & .57 & 7.00 \\
M4 & .78 & .79 & 8.01 \\
M5 & .74 & .75 & 7.82 \\
M6 & .54 & .50 & 6.61 \\
M7 & .54 & .49 & 6.54 \\
M8 & .45 & .40 & 5.68 \\
M9 & .65 & .57 & 7.12 \\
M10 & .72 & .65 & 7.52 \\
M11 & .62 & .58 & 7.10 \\
M12 & .74 & .66 & 7.63 \\
M13 & .50 & .44 & 5.15 \\
\hline
\end{tabular}

\section{Güvenirliğine İlişkin Bulgular}

Ölçeğin iç tutarlılı̆̆ını belirlemek amacıyla Cronbach Alpha değerleri hesaplanmıştır. Ölçeğin Cronbach Alpha değerleri .88 bulunmuştur. Bu değer (Büyüköztürk, Şekercioğlu, ve Çokluk, 2018)'e göre bir ölçek için kabul edilir değerler içinde kalmaktadır. Ayrıca ölçek maddelerine ilişkin madde toplam korelasyonlarının .39 ile .70 arasında değiştiği görülmektedir. Ölçek maddelerinin korelasyon katsayılarını 20 ' den büyük olması o maddelerin ait oldukları boyutun amacına yeterli derecede hizmet ettiğini (Şencan, 2005; Büyüköztürk, 2012; Tavşanc1l, 2019) idafe etmektedir. Bu sebeple ölçekte yer alan ölçek maddelerinin tamamının .39'un üzerinde değer alması, ölçek maddelerinin ayırt edicilik güçleri çok iyi olarak değerlendirilebilir. Elde edilen bu veriler ışığında geliştirilen ölçme aracının güvenirliğinin yüksek olduğu söylenebilir. Güvenirlik ve geçerliliği sağlanmış olan, tek boyut ve 13 maddeden oluşan ölçme aracının son hali Tablo 3'te yer almaktadır.

\section{Tablo 3. Ölçek Maddelerine ait betimsel istatistikler}

\begin{tabular}{lll}
\hline Madde & \multicolumn{1}{l}{$S$} \\
\hline 1-Uzaktan eğitim sistemi coğrafya konularının öğretimi için faydalıdır. & 2.7331 & 1.13044 \\
2-Uzaktan eğitim sistemi coğrafya konularının öğretiminde kolaylık sağlamaktadır. & 2.8315 & 1.15781
\end{tabular}


3-Uzaktan eğitim sistemi daha çok Fiziki Coğrafya konularının öğretiminde yararlı- $\quad 3.3539$

dir.

4-Uzaktan eğitim sisteminde coğrafya öğretim teknikleri rahatlıkla uygulanabilmek-

2.9803

tedir.

5-Uzaktan eğitim sistemi coğrafya konularını öğretme sürecini hızlandırmaktadır.

6-Uzaktan eğitim sistemi coğrafya öğretim materyallerinin çeşitlenmesini sağlamış-

2.6404

1.20559

7-Uzaktan eğitim sistemi sayesinde coğrafya dersinde öğrencilerin defter tutmasına

3.2500

1.25007 gerek kalmamıştır.

8-Uzaktan eğitim sistemi ile Coğrafya dersinde öğretmenin etkinliği artmıştır. $\quad 2.7275$ 9-Uzaktan eğitim sistemi ile coğrafya dersinde öğrencilerin derse katılımı artmıştır.

10-Uzaktan eğitim sisteminde coğrafya öğretmeni olarak derste kendimi daha özgür hissederim.

11-Uzaktan eğitim sisteminde verilen canlı ders sürelerinin coğrafya derslerini yeterli düzeyde verecek seviyededir.

12-Uzaktan eğitim sisteminde coğrafya derslerini ev ortamında verme rahatlı̆̆ derse $\quad 3.4157 \quad 1.22701$ daha çok konsantre olmamı sağlar.

13-Salgın süreci bittikten sonra da coğrafya eğitiminde uzaktan eğitimin yüz yüze $\quad 3.0646 \quad 1.46846$ eğitimle birlikte devam etmesi gerektiğini düşünüyorum.

\section{Doğrulayıcı Faktör Analizine (DFA)Yönelik Bulgular}

Araştırmada, uzaktan eğitim ile coğrafya öğretiminin etkililiği ölçeğinin Açımlayıcı Faktör Analizi (AFA) ile tespit edilen ölçek yapısını doğrulamak için, ölçeğin 13 maddelik yapısı üzerinde Doğrulayıcı Faktör Analizine(DFA) gerçekleştirilmiştir. DFA, bazı ölçüler doğrultusunda AFA yönteminin ortaya çıkardı̆̆ı modeli sınamayı ve modelin uygunluğunu test etmeyi amaçlamaktadır (Şimşek Ö. F., 2007; Sümer, 2000). DFA modelinin geçerliğini değerlendirmek için çok sayıda uyum indeksi kullanılmaktadır (SchermellehEngel, vd. 2003). Bunlar içinde en fazla kullanılanlar ise; İyilik Uyum İndeksi (GFI), Düzeltilmiş İyilik Uyum İndeksi (AGFI), Ortalama Hataların Karekökü (RMR) Ki-Kare Uyum Testi $\left(\chi^{2} / \mathrm{sd}\right)$, ve Yaklaşık Hataların Ortalama Karekökü (RMSEA) şeklinde sıralanmaktadır.

Doğrulayıcı faktör analizi sonuçları ile Açımlayııı Faktör Analizinde ortaya çıkarılan yapının doğrulandığı saptanmıştır. DFA ile elde edilen modele ait uyum değerleri Tablo 4 'te verilmiştir.

Tablo 4. DFA Uyum Sonuçları

\begin{tabular}{llll}
\hline Ölçüm & İyi Uyum & $\begin{array}{l}\text { Kabul } \\
\text { Edilebilir Uyum }\end{array}$ & $\begin{array}{l}\text { Ölçeğin Uyum İndeksi } \\
\text { Değerleri }\end{array}$ \\
\hline$\left(\chi^{2} / \mathrm{sd}\right)$ & $\leq 3$ & $\leq 4-5$ & 3.76 \\
RMSEA & $\leq 0.05$ & $0.06-0.08$ & 0.08 \\
SRMR & $\leq 0.05$ & $0.06-0.08$ & 0.06 \\
CFI & $\geq 0.95$ & $\geq 0.90$ & 0.91
\end{tabular}




\begin{tabular}{llll} 
GFI & $\geq 0.95$ & $\geq 0.90$ & 0.90 \\
IFI & $\geq 0.95$ & $\geq 0.90$ & 0.91 \\
AGFI & $\geq 0.90$ & $0.89-0.85$ & 0.85 \\
\hline
\end{tabular}

(Schermelleh-Engel, vd. 2003; Bryne, 2010; Blunch, 2008; Anderson ve Gerbing, 1984; Marsh, R.Balla ve McDonald, 1988; Çelik ve Yılmaz, 2013).

Tablo 4'te yer alan Doğrulayıcı Faktör Analizi sonucunda elde edilen verilere göre; $\chi 2$ /sd oranı 3.76, RMSEA değeri .08, Root Mean Square Residual (SRMR) değeri .06, Comparative Fit Index (CFI) değeri .91, Goodnes of Fit Index (GFI) değeri .90, Incremental Fit Index $(\mathrm{IFI})=.91$, ve AGFI değeri .85 olarak tespit edilmiştir.

Tablo 4'te görüldüğü üzere DFA sonuçlarına göre, bütün uyum indeksleri kabul edilebilir değerler aldığı için ölçek maddelerinin ilgili yapı ile olan modellerinin uygun olduğu sonucuna ulaşılmıştır.

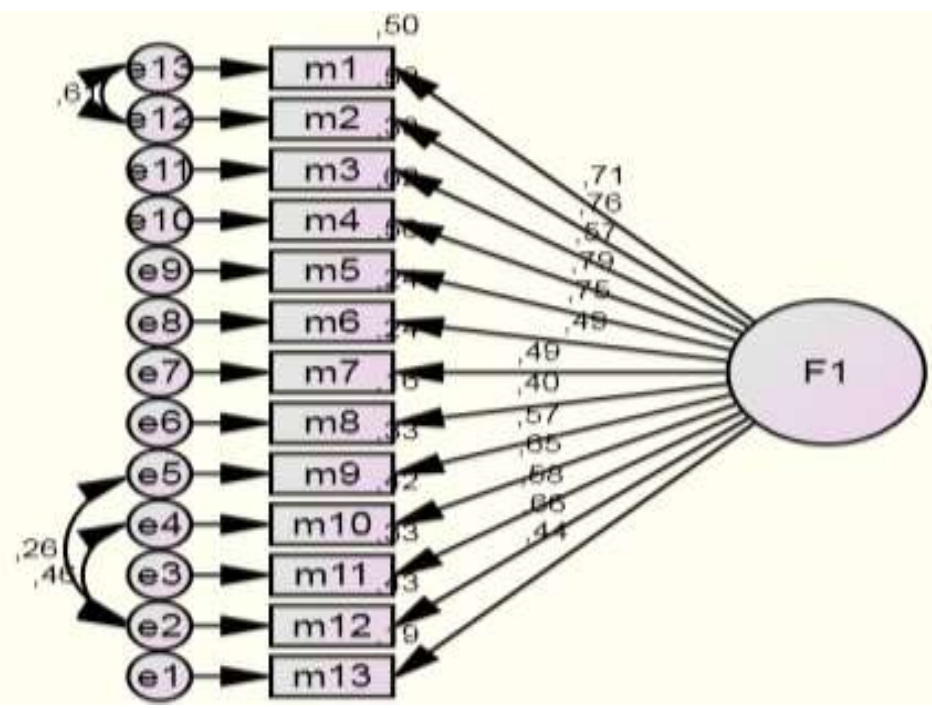

Şekil 1. Doğrulayıcı Faktör Analizine İlişkin yol diyagramı ve faktör yükleri

Doğrulayıcı Faktör Analizine İlişkin oluşturulan diyagram (Şekil 1) incelendiğinde her bir maddenin örtük bağımlı değişken üzerindeki etki miktarları ve korelasyon katsayıları görülmektedir. Ölçekte yer alan maddelerin korelasyon katsayılarının 0.40 ile 0,79 arasında değişim gösterdiği görülmektedir.

\section{Tartışma ve Yorum}


Coğrafya öğretmenlerinin uzaktan eğitim ile coğrafya öğretiminin etkililiğini ölçmek amacıyla gerçekleştirilen araştırma verileri 356 coğrafya öğretmeninden elde edilmiştir. Tabachnick ve Fidell (2001)'e göre araştırma kapsamında faktör analizinin yapılabilmesi için gerekli görülen örneklem büyüklüğü yeterli görülmüştür. Ölçeğin yapı geçerliğini belirlemek için temel bileşenler analizi kullanılarak Açımlayıcı Faktör Analizi (AFA) yapılmıştır. Açımlayıcı Faktör Analizinde faktör yükleri en az .40 olarak belirlenmiştir (Büyüköztürk, 2012). Ölçeğin hem alt boyutları ve hem de toplam yapısı için Cronbach Alpha güvenir katsayısı hesaplanmıştır. Bu doğrultuda AFA ile tespit edilen yapının doğruluğunun test edilebilmesi için Doğrulayıcı Faktör Analizi (DFA) yapılmıştır. Faktör analizine başlamadan önce verilerin uygunluğunu saptamak üzere KMO katsayısı ve Barlett testi hesaplan-mış; KMO değeri .895 ve Bartlett testi sonucu da $\left(\chi^{2}=2060.933, \mathrm{p}=0.00\right)$ anlamlı çıkmıştır (George ve Mallery, 2005; Tavşancıl, 2019). Yapılan test sonucunda KMO değerinin 1'e yaklaşması ölçekteki her bir değişkenin tahmin edilebilirliğini göstermektedir. Barlett Küresellik testi ise verilerin çok değişkenli olduğunu ve normal dağılımdan geldiğini ifade etmektedir (Büyüköztürk, 2012). Ölçek, tek bir yapıyı ölçtüğü için AFA sonucunda da tek faktör (Uzgören, 2012) görülmüştür. Yeterli faktör yükü sağlamayan 5 madde ölçekten çıkartılarak analiz tekrarlanmıştır. Tek faktörlü oluşan yapıda varyans \%43 şeklindedir.

Ölçeğin iç tutarlılık Cronbach Alpha değerleri .88 bulunmuştur. Bu değer Büyüköztürk, vd. (2018)'e göre bir ölçek için kabul edilir değerler arasındadır. Ölçek maddelerine ilişkin madde toplam korelasyonlarının .39 ile .70 arasinda değiştiği görülmüştür. Bir ölçeği oluşturan maddelere yönelik korelasyon katsayısının .20 'den büyük olması, o maddelerin ait oldukları boyutun amacına yeterli seviyede hizmet edebildiğini (Şencan, 2005; Büyüköztürk, 2012; Tavşanc1l, 2019) gösterir. Bu bakımdan ölçek maddelerinin tamamının .39 değerinin üzerinde olması, ayırt edicilik güçlerinin çok iyi olduğu şeklinde değerlendirilebilir. Bu sebeple ölçme aracının güvenirliğinin yüksek olduğu söylenebilir.

Uzaktan eğitim ile coğrafya öğretiminin etkililiği ölçeğinde AFA ile tespit edilen ölçek yapısını doğrulamak amacıyla, ölçek Doğrulayıcı Faktör Analizi (DFA) gerçekleştirilmiştir. DFA, bazı ölçülere bağlı olarak AFA'nın ortaya çıkardığı modeli sınamayı ve uygunluğunu test etmeyi hedefler (Şimşek Ö. F., 2007; Sümer, 2000). Bu doğrultuda DFA modelinin geçerliğini doğrulamak için birçok uyum indeksi kullanılır (Schermelleh-Engel, vd. 2003). Yapılan 
DFA sonucunda elde edilen verilere göre; $\chi 2 / \mathrm{sd}$ oran $1=3.76$, RMSEA değeri $=.08$, SRMR değeri $=.06$, CFI değeri $=.91$, GFI değeri $=.90$, IFI değeri $=.91$, ve AGFI değeri $=.85$ şeklinde tespit edilmiştir. Bu DFA sonuçlarına göre, bütün uyum indeksleri kabul edilebilir seviyede olduğundan, ölçek maddelerinin ilgili yapıyla uyumlu olduğu yargısına ulaşılmıştır. Bu sonuçlar ile, DFA doğrultusunda oluşturulan diyagramda, her bir maddenin örtük bağımlı değişken üzerindeki etki miktarları ve korelasyon katsayıları ile uyumludur.

\section{Sonuç}

Bu araştırmada, coğrafya öğretmenlerinin uzaktan eğitim ile coğrafya öğretiminin etkililiğini ölçmek amacıyla geçerliği ve güvenirliği sağlanmış bir ölçek geliştirilmiştir. Bu amaçla ilgili alan yazın taranarak soru havuzu oluşturulmuş, hazırlanan sorulardan kapsam ve görünüş geçerliliği için uzman görüşleri alındıktan sonra taslak ölçek için ön uygulama gerçekleştirilmiştir. Ön uygulamadan sonra oluşan asıl 18 sorudan oluşan ölçek, 356 coğrafya öğretmenine uygulanmıştır. Temel bileşenler analizinden sonra ortaya çıkan ölçek maddelerinin uyumuna bakmak amacıyla faktör analizi yapılmış, analiz sonuçlarına göre modelin araştırma verisi ile uyumlu olduğu tespit edilmiştir. Tek faktörlü yapının ölçeğe ilişkin açıkladığı varyans \%43.'tür. Yeterli faktör yükü sağlamayan 5 madde ölçekten çıkarılmıştır. Maddelerin faktör yük değerleri 45 ile .78 arasinda değişmektedir. Bu durum ölçeğin madde analizi sonucunda ayırt edici olduğu sonucuna ulaşılmıştır. Ölçeğin tamamına ait Cronbach Alpha iç tutarlık katsayısı 0,88 olarak tespit edilmiştir. Bu sonuçlar, uzaktan eğitim ile coğrafya öğretiminin etkililiğ̣i ölçeğinin geçerli ve güvenilir olduğunu göstermektedir.

Yapılan geçerlik ve güvenirlik analizleri neticesinde 13 maddeden tek faktörden oluşan ölçeğin, coğrafya öğretmenlerinin uzaktan eğitime karşı bakış açılarını ölçmede kullanılabileceği sonucunda ulaşılmıştır.

Covid-19 sebebi ile tüm dünyada olduğu gibi Türkiye' de de uzaktan eğitimin zorunlu olduğu bu dönemde bütün coğrafya öğretmenleri bu deneyimi yaşamaktadırlar. Literatürdeki benzer çalışmalar incelendiğinde uzaktan eğitim ile ilgili çalışmalar olmakla birlikte, sadece coğrafya alanına özgü maddeler ile geliştirilen başka bir ölçek olmadığından ölçeğin coğrafya alanına özgü bir yapısı vardır. Bu sebeple ölçekteki bağımsız değişkenler değiştirilerek, Türkiye'nin diğer illerinde de uygulanabilir ve elde edilen veriler ile yeni 
bulgulardan yola çıkarak uzaktan eğitim konusuna yönelik yeni düzenlemeler yapilabilir.

\section{Etik Kurul Onayı}

Ölçek hazırlandıktan sonra; İstanbul il Milli Eğitim Müdürlüğünden alınan 20.10.2020 tarihli araştırma izni ve Namık Kemal Üniversitesi Bilimsel Araştırma ve Yayın Etiği Kurulu 11.11.2020 tarihli etik kurul onayı ile uygulanmıştir.

\section{Katkı Belirtme}

$\mathrm{Bu}$ çalışmada istatistik veri analizinde bizlere desteklerini esirgemeyen sayın Bülent Dilmaç'a teşekkürü bir borç biliriz. 


\title{
EXTENDED ABSTRACT
}

\section{Effectiveness Scale of Geography Teaching with Distance Education: Scale Development, Validity and Reliability Study}

\author{
Ziya İnce - Murat Mücahit Yentür - Vedat Şahin \\ Namık Kemal University - Ministry of National Education
}

The Covid-19 outbreak, which started in China at the end of 2019, spread to all continents in a short period of 3 months. As in every field, it has caused a great restriction in the field of education, bringing distance education to the agenda. Before the Covid-19 epidemic, distance education was carried out only for the students of open education institutions in Turkey, while it was on the agenda for all students with the epidemic.

This research aims to develop a valid and reliable scale that accurately measures the effectiveness of geography teaching performed by distance education according to the views of geography teachers, and can evaluate quickly and easily. This the research, in the fall semester of the 2019-2020 academic year were implemented.

When the literature is scanned, it is seen that many studies have been conducted under the name of distance education, online education and e-learning. Scale studies developed for distance education are quite abundant. Among these developed scales, those belonging to Ağır, Gür and Okçu (2007), Mishra and Panda (2007), Usta et al. (2016), and Yildız (2015) are important.

When the scale studies prepared on geography education are examined, it is understood that these studies are especially aimed at determining the attitudes of high school students towards geography lesson. Among them include the work of Alım (2003), Özgen (2009), Özgen, Bindak and Birel (2009), Uzunöz (2011), Demir and Koç (2013), Gümüş and Özüpekçe (2013), Çakıcıŏglu-Oban and Aygören (2017), Sözen (2019), Kılcan, Çetin, Ablak, and Gürgür (2019), Deniz, İnel and Sezer (2020). However, a scale tool that measures geography teachers' attitudes towards distance education has not been encountered.

The research was carried out with quantitative research method and descriptive survey design. Scanning pattern is an approach that tries to define a past or present situation as it is. 
While the research universe is composed of geography teachers in the province of Istanbul, the research sample consists of 356 geography teachers in 30 districts of Istanbul. A high sample diversity was provided for the validity of the scope of the research results. Within this framework, the diversity of different schools, the multitude of those working in different working seniorities and the different socio-economic ones have led to the preference of geography teachers in Istanbul, who have what they have.

The scale preparation process of the study took place in two stages. In the first stage, the literature was examined and the opinions of the teachers who teach distance education and geography teaching about distance education were taken. In this context, studies and teachers' opinions were examined. As a result of the researches, an item pool consisting of 30 questions was created on the effectiveness of distance education and geography teaching. Opposite the items, the options such as "(1) I strongly disagree, (2) I do not agree, (3) I am undecided, (4) I agree and (5) I totally agree are added.

Then, expert opinion was consulted and discussed on the form consisting of 30 items. Items with a content validity rate of less than 0.80 were removed from the scale and a 24-item trial form was obtained. Pilot application was carried out with the trial form and the scale was finalized. In the pilot application, items that were incompatible with the overall scale were removed and an 18-item scale was obtained.

Since the schools were on holiday due to the epidemic, the scale was converted to Googleform electronically and the connection was sent to the teachers via phone groups and e-mail. The scale consists of two parts. Demographic information is included in the first part, and scale questions are included in the second part. The data obtained from the teachers were analyzed in the SPSS program.

In the study, exploratory factor analysis (EFA) and confirmatory factor analysis (CFA) were performed to test the validity of the questionnaire. In confirmatory factor analysis, the fit indices $\chi^{2}, \chi^{2} / \mathrm{sd}$, RMSEA, SRMR, CFI, GFI, IFI and AGFI (Schermelleh-Engel, Moosbrugger, \& Müller, 2003) were examined to test the compatibility of the scale structure.

Before starting the factor analysis, Kaiser-Meyer-Olkin (KMO) coefficient and Barlett Sphericity test were calculated to determine the suitability of the data. The KMO value was found to be .895 and the Bartlett test result $\left(\chi^{2}=2060.933, p=\right.$ 0.00 ) was found to be significant.

In order to determine the construct validity of the scale, exploratory factor analysis (EFA) was performed using principal component analysis with varimax 
rotation. In the analysis, factor loadings were determined as at least .40. As a result of EFA, it was observed that the scale was gathered under one factor after 5 items that did not provide sufficient factor loading were removed from the scale. The variance explained by the single factor structure for the scale is $43 \%$. The features of 13 items are presented in Table 2.

Cronbach Alpha values calculated to determine the internal consistency of the scale were found .88. In addition, it is seen that the total item correlations of the scale items ranged from .39 to .70 . It can be said that the reliability of the measurement tool developed in the light of these data obtained is high. The final version of the measurement tool, whose reliability and validity has been ensured, consisting of a single dimension and 13 items, is given in Table 3.

In the study, CFA was performed to verify the scale structure. The fit values of the model obtained with CFA are given in Table 4. As seen in Table 4, according to CFA results, since all fit indices have acceptable values, it has been concluded that the models of the scale items with the relevant structure are appropriate.

As a result, in this study, a valid and reliable scale was developed in order to measure the effectiveness of geography teachers' distance education and geography teaching.

\section{Kaynakça / References}

Ağır, F., Gür, H., ve Okçu, A. (2007). Uzaktan eğitime karşı tutum ölçeği geliştirmesine yönelik geçerlik ve güvenirlik çalışması. E-Journal of New World Sciences Academy, 3(2), 128-139.

Alım, M. (2003). Dokuzuncu sinıf coğrafya öğretim programının öğretmen ve öğrenci görüşlerine göre değerlendirilmesi. Yayımlanmamış Doktora Tezi. Erzurum: Atatürk Üniversitesi, Sosyal Bilimler Enstitüsü, Coğrafya Eğitimi.

Anderson, J., ve Gerbing, D. (1984). The effect of sam- pling error on convergence, improper solutions, and good- ness-of-nt indices for maximum likelihood confirmatory factor analysis. Psychametrika, 49, 155-173.

Blunch, N. (2008). Introduction to structural equation modelling using spss and amos. London: Sage.

Bryne, B. M. (2010). Structural equation modeling with amoS: Basic concepts, applications and programming. (2nd Edition.). Routledge: Taylor \& Francis Group.

Büyüköztürk, Ş. (2005). Anket geliştirme. Türk Eğitim Bilimleri Dergisi 3(2), 133-151.

Büyüköztürk, Ş. (2012). Sosyal bilimler için veri analizi el kitabı. 16.Baskı. Ankara: Pegem Akademi.

Büyüköztürk, Ş., Şekercioğlu, G., ve Çokluk, Ö. (2018). Sosyal bilimler için çok değişkenli SPSS ve LISREL uygulamaları (5. bs). Ankara: Pegem Akademi Yayınları. 
Chou, T.-C. R. (2014). A Scale of university students' attitudes toward e-learning on the moodle system. International Journal of Online Pedagogy and Course Design (IJOPCD), IGI Global,. 4(3), 49-65.

Çakıcıoğlu-Oban, R., ve Aygören, T. (2017). Sosyal bilgiler öğrencilerinin coğrafya dersine yönelik tutum belirleyicileri adındaki çalışma: Pamukkale Üniversitesi örneği. Akademik Sosyal Araştırmalar Dergisi, 5(48), 27-42.

Çelik, E. H., ve Yılmaz, V. (2013). Lisrel 9.1 ile yağısal eşitlik modellemesi. Ankara: Anı Yayınları.

Çepni, S. (2018). Araştırma ve proje çalışmalarına giriş 8.Baskı. Trabzon: Celepler Matbaacilik.

Demir, S. B., ve Koç, H. (2013). Coğrafya dersi tutum ölçeği: geliştirilmesi, geçerlik ve güvenirlik çalışması. Turkish Studies - International Periodical For The Languages, Literature and History of Turkish or Turkic Volume 8(8) Summer, 1765-1777.

Deniz, M., İnel, Y., ve Sezer, A. (2020). Üniversite öğrencilerinin küresel iklim değişikliğine yönelik farkındalık ölçeği. International Journal of Geography and Geography Education (IGGE), 43., 252-264.

Doğanay, H. (2002). Coğrafya öğretim yöntemleri. İstanbul: Aktif Yayınevi 5.Baskı.

Düzakın, E., ve Yalçınkaya, S. (2020). Web tabanlı uzaktan eğitim sistemi ve çukurova üniversitesi öğretim elemanlarının yatkınlıkları. Çukurova Üniversitesi Sosyal Bilimler Enstitüsü Dergisi 17(1), 225-244.

Gelişli, Y. (2015). Uzaktan eğitimde öğretmen yetiştirme uygulamaları: tarihçe ve gelişim. Eğitim ve Öğretim Araştırmalarn Dergisi, 4(3), 313-321.

George, D., ve Mallery, P. (2005). SPSS for Windows step by step: A Simple Guide and Refence, 13.0 update (6th ed.). Boston: Pearson.

Gümüş, N., ve Özüpekçe, S. (2013). Bilgisayar destekli coğrafya öğretimine yönelik bir tutum ölçeği geliştirme çalışması. Turkish Studies - International Periodical For The Languages, Literature and History of Turkish or Turkic Volume 8(8) Summer, 665-677.

Haznedar, Ö., ve Baran, B. (2012). Eğitim fakültesi öğrencileri için e-öğrenmeye yönelik genel bir tutum ölçeği geliştirme çalışması. Ĕ̆itim Teknolojisi Kuram ve Uygulama,2(2), 42-59.

Heuer, B., ve King, K. (2004). Leading the Band: The role of the instructor in online learning for educators. The Journal of Interactive Online Learning 3(1), 1-11.

İnce, Z. (2015). Ortaöğretim coğrafya dersi 10.sınıf müfredatının yaşadığımız çevreyi tanımaya katkısının incelenmesi. Marmara Coğrafya Dergisi, 31, 330-344.

Karakoç, F. Y., ve Dönmez, L. (2014). Ölçek geliştirme çalışmalarında temel ilkeler. Tıp Ĕ̆itimi Dünyası, 13(40),, 39-49. 
Karasar, N. (2013). Bilimsel araştırma yöntemi. Ankara: Nobel Akademik Yayıncılık, 25.Basim.

Kılcan, B., Çetin, T., Ablak, S., ve Gürgür, M. (2019). Beşeri coğrafya dersine yönelik tutum ölçeğinin geliştirilmesi: Geçerlik ve güvenirlik çalışmaları. Cumhuriyet International Journal of Education, 8(4), 913-927. http://dx.doi.org/10.30703/cije.538710.

Kocalar, A. O.,ve Demirkaya, H. (2017). Geography teachers' views on effective geography teaching. Review of International Geographical Education Online, 332346.

Köse, E. (2017). Bilimsel araştırma modelleri. R. Y. Kıncal (Ed.) içinde, Bilimsel Araştırma Yöntemleri 5.Basım içinde (s. 99-124). Ankara: Nobel Akademik Yayıncllık Eğitim Danışmanlık.

Kurnaz, E., ve Serçemeli, M. (2020). Covid-19 pandemi döneminde akademisyenlerin uzaktan eğitim ve muhasebe eğitimine yönelik bakış açıları üzerine bir araşturma. USBAD Uluslararası Sosyal Bilimler Akademi Dergisi 2(3), 262-288.

Landau, S., \& Everitt, B. S. (2004). A handbook of statistical analyses using SPSS. Florida: Boca Raton, FL: Chapman \& Hall / CRC.

Lee, J., \& Busch, P. (2005). Factors related to instructors' willingness to participate in distance education. The Journal of Educational Research 99(2), 109-115.

Marsh, H. W., R.Balla, J., ve McDonald, R. P. (1988). Good- ness of fit indexes in confirmatory factor analysis: The effect of sample size. Psychological Bulletin, 103, 391-410.

MEB. (2020, 03 12). Milli Ĕgitim Bakanlı̆̆ı. https://www.meb.gov.tr/bakan-selcuk-koronaviruse-karsi-egitim-alaninda-alinan-tedbirleri-acikladi/haber/20497/tr 13.11.2020 tarihinde adresinden alınmıştır

Mishra, S., ve Panda, S. (2007). Development and factor analysis of an instrument to measure faculty attitude towards e-learning. Asian Journal of Distance Education, 5(1), 27-33.

Özey, R. (2002). Türkiye coğrafyası ve jeopolitiği. İstanbul: Aktif Yayınevi.

Özgen, N. (2009). Lise öğrencilerinin coğrafya dersine yönelik tutumlarının çeşitli değişkenlere göre incelenmesi: Siirt Örneği. Gazi Üniversitesi, Gazi Ĕ̆itim Fakültesi Dergisi, 29(2), 421-440.

Özgen, N., Bindak, R., ve Birel, F. K. (2009). Coğrafya dersine yönelik bir tutum ölçeğinin geliştirilmesi. Mehmet Akif Ersoy Üniversitesi, Ĕ̆itim Fakültesi Dergisi, 13, 58-64. 
Özgöl, M., Sarıkaya, İ., ve Özürk, M. (2017). Örgün eğitimde uzaktan eğitim uygulamalarına ilişkin öğrenci ve öğretim elemanı değerlendirmeleri. Yükseköğretim ve Bilim Dergisi 7(2), 294-304.

Özkul, A. E., ve Aydın, H. (2012). Öğrenci adaylarının açk ve uzaktan öğrenmeye yönelik görüşleri. Akademik Bilişim 2012, Uş̧ak: Uşak Üniversitesi. https://ab.org.tr/ab12/bildiri/42.pdf.

Pınar, M. A., ve Akgül, G. D. (2020). The opinions of secondary school students about giving science courses with distance education during the Covid-19 Pandemic. Journal of Current Researches on Social Sciences, 10 (2), 461-486.

Reimers, F. M., ve Schleicher, A. (2020). A framework to guide an education response to the COVID-19 Pandemic of 2020. OECD Publishing (http://www.oecd-ilibrary.org): $\quad$ https://read.oecd-ilibrary.org/view/?ref=126_126988t63lxosohs\&title=A-framework-to-guide-an-education-response-to-the-Covid-19-Pandemic-of-2020 12.11.2020 tarihinde adresinden alınmıştır

Schermelleh-Engel, K., Moosbrugger, H., ve Müller, H. (2003). Evaluating the fit of structural equation models: Tests of significance and descriptive goodnessof-fit measures. Methods of Psychological Research Online 8(2), 23-74.

Sözen, E. (2019). Coğrafya dersi tutumu, coğrafya ders işlenişi ve materyal kullantmına yönelik ölçek geliştirilmesi, geçerlik ve güvenirlik çalışması. Anadolu Eğitim Liderliği ve Öğretim Dergisi 7 (1), 1-14.

Sümer, N. (2000). Yapısal eşitlik modelleri: temel kavramlar ve örnek uygulamalar. Türk Psikoloji Yazıları, 3 (6),, 49-74.

Şahin, V. (2017). First-year student views on geography as a department and as a profession. Kastamonu Üniversitesi Kastamonu Eğitim Dergisi, 25, 1651-1658.

Şencan, H. (2005). Sosyal ve davranışsal ölçümlerde güvenilirlik ve geçerlilik. Ankara: Seçkin Yayınclik.

Şimşek, A. (2018). Araştırma Modelleri. A. Şimşek Sosyal Bilimlerde Araştırma Yöntemleri içinde, (s. 80-107). Eskişehir: Anadolu Üniversitesi Açıöğretim Fakültesi Yayını No: 1619.

Şimşek, Ö. F. (2007). Yapısal Eşitlik Modellemesine Giriş - Temel İlkeler ve LISREL Uygulamaları. Ankara: Ekinoks Yayınları.

Tabachnick, B. G., ve Fidell, L. S. (2001). Using multivariate statistics (4th edition). Needham Heights: Allym \& Babon.

Tavşancil, E. (2019). Tutumları Ölçülmesi ve SPSS İle Veri Analizi. (6. Baskı). Ankara: Nobel Yayınları.

Teyfur, E. (2016). Coğrafya öğretmen adaylarının web destekli işbirlikli öğrenme ortamlarına yönelik görüşleri. Education Sciences (NWSAES), 11(3), 153-167. 
Thach, E., ve Murphy, K. (1995). Competencies for distance education Professionals. Educational Technology Research and Development 43(1), 57-79.

Toker-Gökçe, A. (2008). Küreselleşme sürecinde uzaktan eğitim. D.Ü.Ziya Gökalp Ĕ̆gitim Fakültesi Dergisi 11, 1-12.

Türker, A., ve Dündar, E. (2020). Covid-19 pandemi sürecinde eğitim bilişim ağı (EBA) üzerinden yürütülen uzaktan eğitimlerle ilgili lise öğretmenlerinin görüşleri. Millî Eğitim, 49 Özel Sayı(1), 323-342.

UNESCO. (2020, 09 01). Policy Paper 42, Act Now:Reduce the impact of COVID-19 on the cost of achieving SDG 4. Global Education Monitoring Report UNESCO France: www.unesco.org/gemreport 14.11.2020 tarihinde adresinden alınmiştır

Usta, İ., Uysal, Ö., ve Okur, M. R. (2016). Çevrimiçi öğrenme tutum ölçeği: geliştirilmesi, geçerliği ve güvenirliği. Uluslararası Sosyal Araştırmalar Dergisi 9(43), 2215-2222.

Uzunöz, A. (2011). Coğrafya dersine yönelik öğrenci tutum ölçeği geliştirilmesi. e-Journal of New World Sciences Academy, 6(1), 1264-1275.

Ünlü, M. (2014). Coğrafya öğretimi. Ankara: Pegem Akademi.

WHO. (2020, 11 14). World Health Organisation Coronavirus Disease (COVID-19) Dashboard. https://covid19.who.int/ 14.11.2020 tarihinde adresinden alınmıştır

Yazıcı, Ö. (2015). Coğrafya bölümü uzaktan eğitim öğrencilerinin fiziki coğrafya içerikli derslere ilişkin görüşlerinin incelenmesi. Zeitschrift für die Welt der Türken (ZfWT) 7(3), 213-232.

Yazıcıoğlu, Y., ve Erdoğan, S. (2014). SPSS Uygulamalı Bilimsel Araştırma Yöntemleri. Ankra : Detay Yayınları.

Yentür, M. (2019). Coğrafya öğretmenlerinin akademik ee yönetimsel hedeflerinin tespiti. Yayınlanmamış doktora tezi. İstanbul: Marmara Üniversitesi, Eğitim Bilimleri Enstitüsü, Ortaöğretim Sosyal Alanlar Anabilim Dalı, Coğrafya Öğretmenliği Bilim Dall.

Yeşil, R. (2014). Nicel ve nitel araştırma yöntemleri. R. Y. Kuncal Bilimsel Araştırma Yöntemleri içinde (s. 51-80). Ankara: Nobel Yayınları.

Yıldırım, A., ve Şimşek, H. (2013). Sosyal Bilimlerde Nitel Araştırma Yöntemleri. Ankara: Seçkin Yayınclık Dokuzuncu Baskı.

Yıldırım, S., Yıldırım, G., Çelik, E., ve Karaman, S. (2014). Uzaktan eğitim öğrencilerinin uzaktan eğitime yönelik görüşleri: bir öçek geliştirme çalışması. Eğitim ve Öğretim Araştırmalarn Dergisi, 3(3), 365-370.

Yıldız, M. (2015). Uzaktan eğitim programlarında ders veren öğretim elemanlarmın uzaktan eğitime yönelik bilgi, inanç ve uygulamalan arasındaki ilişkiler. Yayınlanmamış 
Yüksek Lisans Tezi, Ankara: Hacettepe Üniversitesi, Bilgisayar ve Öğretim Teknolojileri Eğitimi Anabilim Dalı, Bilgisayar ve Öğretim Teknolojileri Eğitimi Bilim Dalı.

Yılmaz, E., Güner, B., Mutlu, H., Doğanay, G., ve Yılmaz, D. (2020). Veli Algisına Göre Pandemi Dönemi Uzaktan Eğitim Sürecinin Niteliği. Konya: Palet Yayınları.

Yılmaz, M. (2020). 20 Nisan 2020 Tarihi itibariyle Covid-19 virüsünün dünyadaki coğrafi (kıtalara ve ülkelere göre) dağılımı. Avrasya Sosyal ve Ekonomi Araştırmalan Dergisi (ASEAD), Eurasian Journal of Researches in Social and Economics (EJRSE) ISSN:2148-9963 7(4), 17-44.

\section{Kaynakça Bilgisi / Citation Information}

İnce, Z., Yentür M.M. ve Şahin, V. (2021). Uzaktan eğitim ile coğrafya öğretiminin etkililiği ölçeği: ölçek geliştirme, geçerlik ve güvenirlik çalışması. OPUS-Uluslararası Toplum Araştırmaları Dergisi, 17(Pandemi Özel Sayıs1), 3943-3966. DOI: 10.26466/opus.879897 